\title{
4차 산업혁명과 주요 국가별 전략 \\ : 선진국 및 아세안(ASEAN) 일부 국가를 중심으로
}

목차

I. 서론

II. 4차 산업혁명 관련 주요 개념

1. 4차 산업혁명의 일반 개념

2. 주요 국가별 배경 및 사례

III. 국가별 추진 현황

1. 주요 선진국

2. 아세안(ASEAN) 국가

IV . 시사점 및 맺음말

참고 문헌 


\section{요 약}

4차 산업혁명에 대한 본격적인 논의가 시작된 지 수년이 지났음에도 불구하고, 아직도 4 차 산업혁명의 개념에 대해서조차 다양한 논란과 혼란이 지속되고 있는 것이 현실이다. 이에 본고에서는 4 차 산업혁명에 대한 그간의 이슈를 총 정리하여, 4 차 산업혁명에 대한 명확한 개념을 제시하고자 하였다. 우선, 디지털 변혁으로 추진되는 4차 산업혁명은 기존 생산 시스템의 지능-자율화를 통하여 산업 생태계를 재편할 것으로 예상되나, 이의 성공적 추진에 있어 정보기술과 생산·운영기술 간의 긴밀한 연계와 공진화가 중요하다는 것이다.

아울러, 최근에는 아세안 및 중동의 개발도상국에서도 관련 논의가 가파르게 증가하고 있다. 하지만, 현재 추진되고 있는 4 차 산업혁명 대응 기술은 결코 단기간에 이루어진 것이 아니라, 장기간의 기술개발 및 비즈니스 모델을 도출하려는 노력의 결과다, 따라서 각 국가 및 기업의 4차 산업혁명 대응 전략 역시 자국 및 해당 기업의 실정에 부합하도록 추진되어야만 한다. 이미 다수의 글로벌 강소국은 자국의 차별화된 산업 특성 또는 기술 전략을 근거로 정책을 추진하고 있으며, 이를 기반으로 글로벌 협력을 추진하고 있다. 


\section{I. 서론}

'4차 산업혁명(4th Industrial Revolution, 이하 4IR)'에 대한 논의가 수년간 이어졌음에도

불구하고, 특히 국내 인문사회과학 분야에서는 아직도 4IR의 본질적 측면에서 여러 논란이

있는 것이 사실이다. 예를 들면 왜 4차인지, 진화인지, 혁신인지 또는 어떤 미래 기술이 그 중심을 차지할지 등이 이에 포함된다.

본고에서는 우선 $4 \mathrm{IR}$ 의 기반이 된 선진국의 일부 사례를 살펴봄으로써, $4 \mathrm{IR}$ 의 본질에 대한

좀 더 올바른 이해를 살펴보고자 하였으며, 이들 사례와 연계하여 $4 \mathrm{IR}$ 의 국가별 전략과 그

방향에 대하여 간략하게 살펴보고자 하였다. 아울러, 주요 동남아시아국가연합(Association of

South-East Asian Nations, 이하 아세안) 국가의 현황과 발전 방안에 대해서도 언급하고자 하였다.1)

1) 본 원고는 저자의 기존 발표 및 출간한 내용을 기반으로 재정리 및 보완·수정된 것임. 


\section{4차 산업혁명 관련 주요 개념}

\section{4차 산업혁명의 일반 개념}

기존의 다양한 논의를 종합해 보면, 4IR은 정보기술(Information Technology, 이하 IT) 분야의 획기적인 발전을 통해 모든 물리적 영역의 경계가 없어지고 또 융합이 가속화되어 기존과 완전히 다른 체계의 생산·소비 패러다임, 즉 실시간 수요를 반영한 온디맨드(on-demand) 디지털 경제사회를 일컫는 의미로 정의할 수 있다. 이와 같은 변화는 클라우드 및 빅데이터를 통한 광범위하고 또 대용량의 실시간 현실 데이터 축적, 사물인터넷(Internet of Things, 이하 IoT)을 통한 모든 물리 영역의 초연결 상태, 이를 기반으로 인공지능을 통한 데이터의 지속적인 분석 활동을 통한 디지털화 기반의 변혁을 의미한다.

한편, 산업혁명 자체가 기존 방식을 획기적으로 변혁한다는 측면에서 볼 때, 1 차와 2 차 산업혁명은 각각 동력원으로서 기계의 육체노동 대체와 전기에너지 출현과 깊은 관련이 있다. 반면, 3 차와 4차 산업혁명은 정보화로 인한 기계의 지식노동 대체라는 측면에서 그 관점이 다르다.

〈표 1〉 각 산업혁명의 단계별 변화

\begin{tabular}{|c|c|c|c|c|c|}
\hline \multicolumn{2}{|c|}{ 구분 } & 1차 산업혁명 & 2차 산업혁명 & 3차 산업혁명 & 4차 산업혁명 \\
\hline \multicolumn{2}{|c|}{ 시기 } & 18세기 후반 & 19 20세기 초 & 20세기 후반 & 2000년대 이후 \\
\hline \multicolumn{2}{|c|}{ 연결성 } & $\begin{array}{l}\text { 국가 내부 } \\
\text { 연결성 강화 }\end{array}$ & $\begin{array}{c}\text { 기업·국가 간 연결성 } \\
\text { 강화 }\end{array}$ & $\begin{array}{c}\text { 사람·환경·기계의 } \\
\text { 연결성 강화 }\end{array}$ & $\begin{array}{c}\text { 자동화·연결성의 } \\
\text { 극대화 }\end{array}$ \\
\hline \multicolumn{2}{|c|}{ 최초 사례 } & $\begin{array}{l}\text { 방직기 } \\
(1784)\end{array}$ & $\begin{array}{c}\text { 신시내티 도축장 } \\
\text { (1870) }\end{array}$ & $\begin{array}{c}\text { PLC : Modicon } 084 \\
\text { (1969) }\end{array}$ & - \\
\hline \multirow{2}{*}{\multicolumn{2}{|c|}{$\begin{array}{l}\text { 혁신 } \\
\text { 동인 }\end{array}$}} & $\begin{array}{c}\text { 증기기관 } \\
\text { (Steam Power) }\end{array}$ & $\begin{array}{c}\text { 전기에너지 } \\
\text { (Electric Power) }\end{array}$ & $\begin{array}{c}\text { 컴퓨터, 인터넷 } \\
\text { (Electronics \& IT) }\end{array}$ & $\begin{array}{l}\text { loT, 빅데이터, Al 기반 } \\
\quad \text { 초연결 } \\
\text { (Hyper-Connection, CPS*) }\end{array}$ \\
\hline & & \multicolumn{2}{|c|}{ 동력원의 변화 (유형 자산 기반) } & \multicolumn{2}{|c|}{ 정보처리방식의 변화 (무형 자산 기반) } \\
\hline \multirow{3}{*}{ 특징 } & 원인 & 기계화 & 전기화 & 정보화 & 지능화 \\
\hline & \multirow[t]{2}{*}{ 결과 } & \multirow{2}{*}{$\begin{array}{c}\text { 산업화 } \\
\text { (Industrialisation) }\end{array}$} & \multirow{2}{*}{$\begin{array}{c}\text { 대량 생산 } \\
\text { (Mass Production) }\end{array}$} & $\begin{array}{c}\text { 자동화 } \\
\text { (Automation) }\end{array}$ & $\begin{array}{c}\text { 자율화 } \\
\text { (Autonomisation) }\end{array}$ \\
\hline & & & & 기계, SW가 데이터를 생신 & 데이터가 기계, SW를 제어 \\
\hline \multicolumn{2}{|c|}{ 현상 } & $\begin{array}{c}\text { 영국 섬유공업의 거대 } \\
\text { 산업화 }\end{array}$ & $\begin{array}{c}\text { 컨베이어 벨트 활용 기반 } \\
\text { 대량 생산을 달성한 } \\
\text { 미국으로 패권 이동 }\end{array}$ & $\begin{array}{c}\text { 인터넷 기반의 디지털 } \\
\text { 혁명, 미국의 글로벌 } \\
\text { IT기업 부상 }\end{array}$ & $\begin{array}{c}\text { 사람·시물·공간의 초연결, } \\
\text { 초지능화를 통한 } \\
\text { 산업구조 개편 }\end{array}$ \\
\hline
\end{tabular}

출처: 김상훈 $(2017 \mathrm{c})$ 에서 재인용 
이와 같은 4IR에 대한 정의는 심지어 영국 국회에서도 많은 논쟁거리(2016. 9.)가 된 바 있는데, 최근 일각에서는 이와 같은 정의 및 차수 논의 자체에 함몰되는 것을 두고 우려를 표현하는 사례도 발생하고 있다. 이들은 $4 \mathrm{IR}$ 의 미래 파급력에 동의하면서도, '4차 산업혁명' 이라는 단어 자체는 버즈 워드(buzzword)에 지나지 않는 것으로 간주하고 있다. 아울러, 4IR 정의에 대한 소모적인 논쟁을 없애기 위해 '4th Industrial Revolution(4IR)'이라는 용어 대신 'New Industrial Revolution(이하, NIR)'이라는 용어를 사용하는 사례도 발견되고 있다.2)

그것이 $4 \mathrm{IR}$ 이든 NIR이든 간에 이들의 핵심은 각종 산업과 기술에서 생성되는 정보의 단순한 산출이나 축적과 이동에 그치지 않고, 실시간의 완전한 연결성을 통한 대량 정보의 생성, 소통 및 융합 그리고 이를 기반으로 한 지능화를 통하여 연결된 모든 것의 자율화를 추진하는 데에 있다. 즉, 산업혁명의 핵심 키워드는 초연결(hyper-connectivity) 기반의 지능화(intelligence)를 통한 자율화(autonomisation)라고 보는 것이 타당하다. 이런 측면에서 $4 \mathrm{IR}$ 은 기존부터 논의되어 온 디지털 변혁과 다르지 않으며, 오히려 4차 산업혁명의 주요 동인이 각 산업 또는 기술 분야에서 추진되고 있는 디지털화인 것이다.

〈그림 1〉 디지털 변혁과 4차 산업혁명

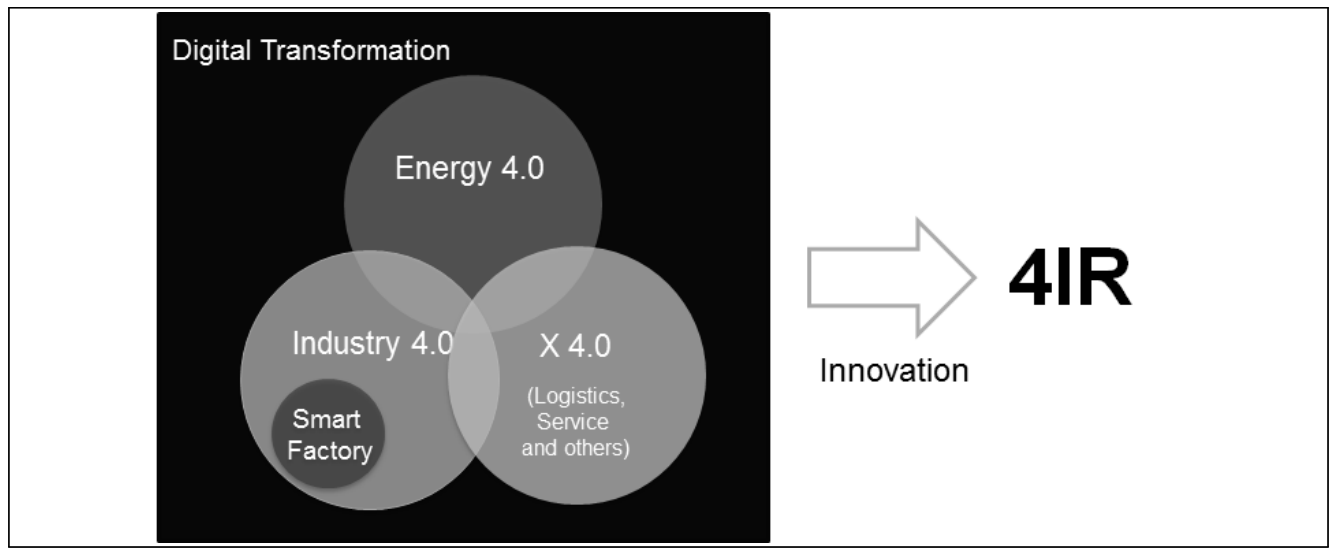

출처: 저자 작성

여기서, Industry 4.0은 2011년 Hannover Messe에서 공식적으로 발표된 독일의 Industrie 4.0에서 유래된 것으로 많이 알려져 있다. 이 Industrie 4.0은 당초 기존 제조업의 디지털화를 통한 디지털팩토리 또는 스마트팩토리를 기반으로 추진되는 스마트제조 즉, 제조

2) NIR 역시 새로운 용어는 아니며, 2010년대 이후 Forbes 등 다양한 매체에서 New Industrial Revolution이라는 용어를 사용한 바 있다. 본 용어가 본격적으로 사용된 계기는 Wired의 편집장이었던 Chris Anderson의 『Makers: The New Industrial Revolution』이라는 책이 출간된 후부터로 보는 것이 타당하다. 
혁신 프로그램을 지칭한다. 다시 말해, 4차 산업혁명과 구분되는 IT화를 통한 제조업 혁신 전략을 일컫는 것이었으나, 최근에는 그 의미가 확장되어 다양한 분야에서 혼용되고 있는 실정 이다.3)

〈그림 2〉 4차 산업혁명과 제조 혁신으로서의 Industrie 4.0

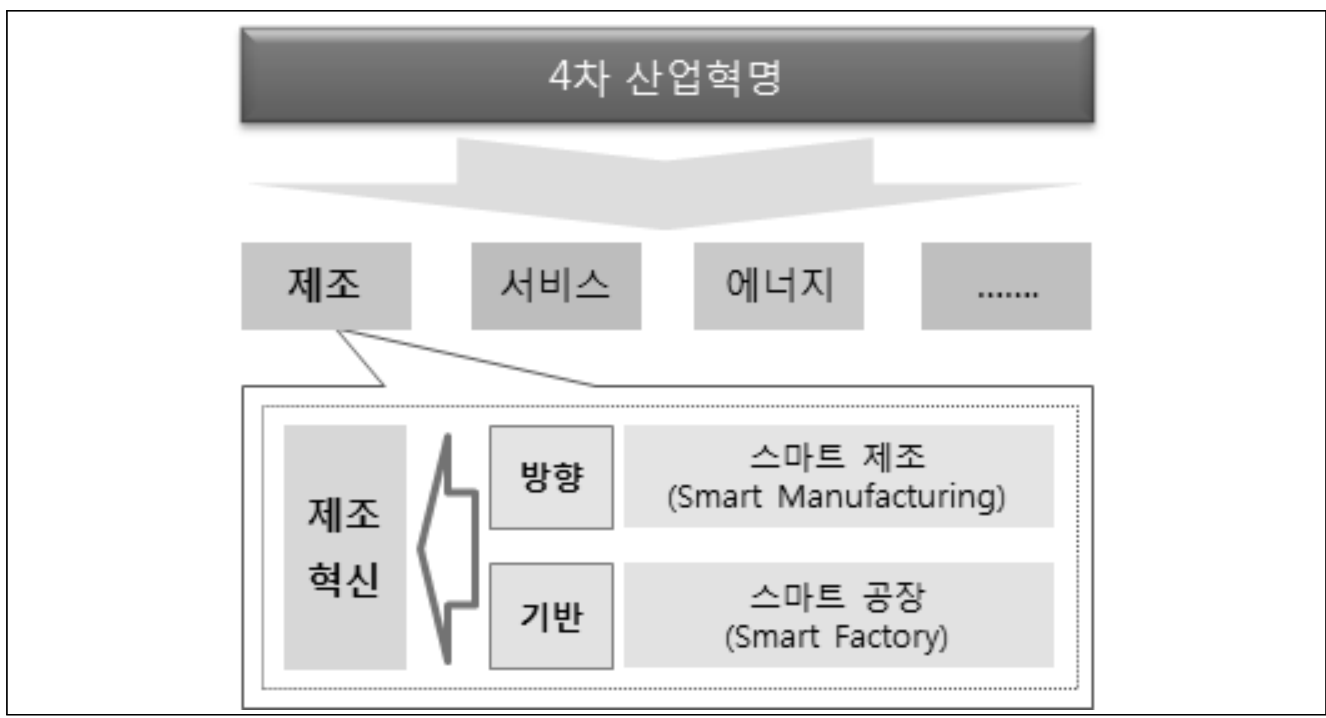

출처: 김상훈 $(2017 \mathrm{c})$ 에서 재인용

독일뿐 아니라 선진국에서는 제조 혁신을 통한 스마트 제조의 성공적인 추진을 위해서는 단순히 정보통신기술(Information and Communication Technology, 이하 ICT) 분야의 발전이 아니라, 촉진기술(Enabler)로서의 정보기술(Information Technology, 이하 IT)과, 이를 필요로 하는 수용기술(Adopter)로서의 생산기술(Operational Technology, 이하 OT) 간 융합이 필수적임을 지속적으로 강조하고 있다. 즉, 이들 기술은 상호 공진화(Co-evolution) 관계에 있음을 인지하는 것이 중요하며, OT 수준에 적합한 IT의 공급 또는 IT 공급에 적합한 $\mathrm{OT}$ 의 개발이 가장 중요한 성공 요인 중의 하나다. 그럼에도 불구하고, 대부분의 경우에 '디지털화' 라는 이슈에 매몰되어 OT를 고려하지 않은 IT에만 집중하는 현상이 종종 발견되고 있는 것이 사실이다.

이와 같은 IT-OT 융합 및 공진화의 중요성 때문에 독일은 물론 미국, 일본과 더불어 최근 $4 \mathrm{IR}$ 에 적극적으로 대응하고 있는 영국, 프랑스, 네덜란드, 호주 및 싱가포르 등도 자국의 현실과

3) 이와 같은 혼용 사례와 대조적으로 디지털화에 기반을 둔 다양한 분야의 혁신을 달리 칭하기도 함. 예: 제조 혁신 (Indusdtry 4.0), 서비스 혁신(Service 4.0), 에너지 혁신(Energy 4.0), 중소기업 혁신(SME 4.0), 금융 혁신 (Finance 4.0) 및 시장 혁신(Market 4.0) 등 
국가 혁신 전략과의 일관성을 감안하여 제조 분야별 Enabler와 Adopter를 구분해 별도의 세부 발전 전략을 고려하고 있는 상황이다.

\section{〈그림 3〉 4IR과 Industry 4.0 및 IT-OT 융합}

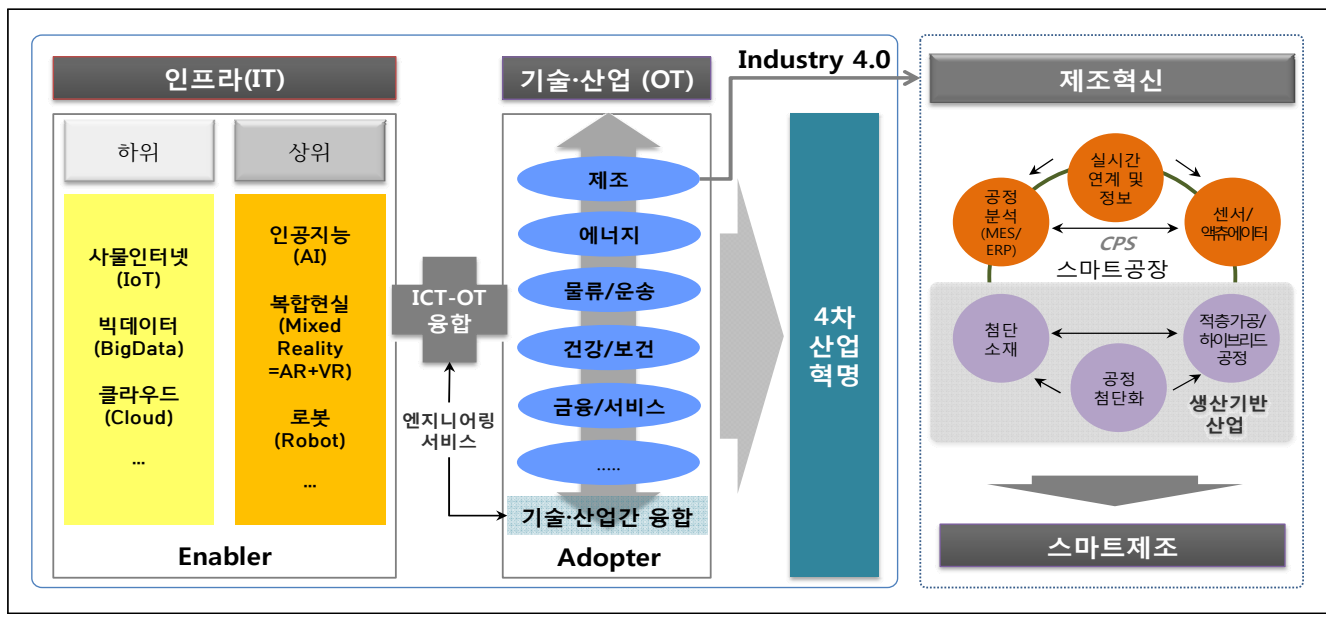

출처: 김상훈 $(2017 a, b, c)$ 에서 재인용 및 일부 수정

아울러, IT-OT의 최적화된 융합은 제품 자체의 진화와 가치사슬의 진화에 모두 관련되어, 소위 System of System을 형성하여 구성 시스템 간의 단순 합 이상의 파급효과를 보일 것으로 예상된다.

\section{2. 주요 국가별 배경 및 시례}

본 절에서는 $4 \mathrm{IR}$ 의 최고 선도국으로 거론되는 독일과 미국에서, 실제 어떤 과정을 거쳐 현재의 4IR이 추진되고 있는지 간략하게 살펴보고자 하였다. 독일의 경우에는 2011년 Hannover Messe에서의 Industrie 4.0 발표 이전의 관련 전략 및 정책 동향을 살펴보는 한편, 미국의 경우에는 가장 잘 알려진 사례 중 하나인 $\mathrm{GE}(\mathrm{General} \mathrm{Electric)사의} \mathrm{Predix} \mathrm{발전} \mathrm{배경을}$ 서술하였다. 이들 두 사례 모두 현재의 $4 \mathrm{IR}$ 관련 위치를 점유하기 위해서 우리가 일반적으로 알고 있는 것 이상으로, 오랜 기간 동안 부단한 관심과 노력이 지속되어 온 점은 시사하는 바가 크다.

\section{1) 독일}

전통적으로 기계 장비 및 부품에서 세계적 경쟁력을 보유한 독일은 2000년대 초반부터 이들 
장비가 가동되는 플랫폼으로서의 공장(Factory)에 대하여 주목하기 시작하였다. 특히, 2005년경 부터 디지털팩토리라는 용어가 대두되고, 산·학-연을 망라하여 이에 대한 연구 및 논의가 활발 하게 진행되었다.

이들 논의에서 중요한 사항 중 하나는 공장을 하나의 복잡한 제품으로 보는 시각인 'Factories as a Products' 관점이며, Westkamper 등은 제조공장에 대하여 'Factories are complex products'라고까지 표현하기 시작하였다. 공장에 대한 이와 같은 시각은 2000년대 중·후반의 전 세계 경제성장 둔화 및 중국 등 신흥국 출현으로 인한 경쟁 심화 환경과 맞물려 있다. 이에 독일을 ‘전 세계의 제품·부품을 만드는 공장'에서 '전 세계의 공장을 만드는 공장' 으로 전략 및 정책 포지셔닝의 진화를 유도하는 데 핵심적인 역할을 하게 된다. 아울러, 이와 같은 관점은 제품으로서의 ‘디지털팩토리’의 타당성을 높여 주었으며, 이후 ‘스마트팩토리’ 개념으로 발전하게 된 단초를 제공해 주게 된다.

한편, 비슷한 시기에 기계장비 자체 측면에서도 장기적 발전 전략을 마련하는 데 다양한 시도가 추진되기 시작하였다. 당시 독일은 기계장비의 중앙 제어 모듈로서의 임베디드 시스템 (embedded system)과 관련해 소프트웨어 부문에서도 전 세계적인 기술 수준을 보유하고 있었다. 그러나 앞서 언급한 다양한 환경 변화에 대응하고 독일의 경쟁력을 지속적으로 유지하기 위해 VDMA(Verband Deutscher Maschinen- und Anlagenbau), VDI(Verein Deutscher Ingenieure), BITKOM(Bundesverband Informationswirtschaft, Telekommunikation und neue Medien), ZVEI(Zentralverband Elektrotechnik- und Elektronikindustrie) 등 다양한 분야의 관련 협회가 중심이 되어 관련 논의를 한 결과, 2009년에 'Nationale Roadmap Embedded Systems'을 발표하기에 이른다. 또한 독일의 이공학한림원인 ACATECH(Deutsche Akademie der Technikwissenschaften)는 2010년 6월, 공식적으로 'Agenda CPS'를 발표 하였다. 주요 내용 중 임베디드 시스템 간의 네트워크를 광역 네트워크 개념으로 발전시키는 사항 등을 포함하고 있다.

독일은 이미 상기의 'Nationale Roadmap Embedded Systems'이 발표되기 이전부터 전통적인 임베디드 시스템이 연결되어 시스템의 시스템(System of systems, 이하 SoS)으로 진화하였다. 이 경우, SoS의 구조가 단순 시스템의 합과 다르다고 이해하였으며, 그렇기 때문에 특별한 관심이 필요한 것으로 보고 있었다. Kopetz 등 다양한 연구자는 임베디드 시스템과 데이터베이스가 연결되면 이와 같은 현상이 발생할 것으로 예상하고, 구성 시스템, SoS 수준에서의 현상, 기획되지 않은 구성 시스템의 진화, 구성 시스템의 오류 등 다양한 분야에서 SoS에 대한 연구의 중요성을 역설한 바 있다. 이와 같은 예상은 이미 일부에서 현실로 발생하고 있다. 
현재 독일의 Industrie 4.0은 상기의 논의와 전략 등을 포함 또는 근거로 하여 발전한 것이 사실이며, 그 기술적 구성과 절차가 일부 변경되었음에도 불구하고 초창기부터 관련 논의에 참여한 VDMA, ZVEI, BITKOM 및 ACATECH 등이 현재도 핵심 논의기구로서 그 역할을 지속적으로 수행하고 있다. 즉, 독일에서 Industrie 4.0 추진은 이미 20년에 육박하는 오랜 기간을 기반으로 하고 있으며, 다양한 이해관계자가 변함없이 관련 사항을 지속적으로 논의하는 점은 주목할 필요가 있다.

\section{2) 미국}

미국에서는 $4 \mathrm{IR}$ 과 관련하여, $\mathrm{GE}$ 의 $\operatorname{Predix}^{\mathrm{TM}}$ (이하 Predix)가 성공 사례로 자주 거론되고는 한다. Predix는 산업인터넷 플랫폼을 구축하여 디지털화를 위한 전사적 플랫폼으로 활용을 시작하여 많은 관심이 집중되고 있다. Predix는 2015년 GE가 발표한 클라우드 기반의 PaaS (Platform-as-a-Service)로, 산업 기계·설비에서 발생하는 대규모 데이터를 수집·분석하는 클라우드 솔루션이다. 현재 $\mathrm{GE}$ 는 전 세계에 1 조 달러 이상의 가치를 지닌 400 여 개 이상의 제조 시설이 있는데, 이들의 효율적인 운용을 위하여 1 천만여 개의 센서를 장착한 후 매일 5 천만 개 이상의 데이터 요소를 모니터링·분석하고 있다. Predix는 이를 위하여 개발된 통합 플랫폼이다. 특히, Predix는 플랜트 및 제조 시설뿐 아니라, 최첨단 제조 기술과 생산공정이 집약된 분야인 항공기 엔진 생산에 활용되고 있는데, GE Aviation의 항공기 엔진 사업이 대표적인 적용 사례다.

사실, Predix의 기원은 현재 가장 널리 이용되는 민항기 중 하나인 보잉의 B777의 개발과 관련이 있다. 1995년에 최초 운항된 B777은 ETOPS4)-180 이상의 성능으로, 당시로서는 대서양 횡단이 가능한 최초의 쌍발 광동체기다. 따라서 B777에는 새로운 엔진이 필요했고, 다른 2개의 경쟁 업체와 비교하여 상대적으로 동 분야 시장점유율이 낮았던 $\mathrm{GE}$ 는 약 20 억 달러를 투자하여 신개념 엔진인 GE90을 개발하기로 하였다. 하지만, 개발된 엔진은 가장 높은 추력 엔진이었음 에도 불구하고 개발 및 인증이 지연되는 사태가 발생하였다. 또한 당시에는 항공사들이 고출력을 활용할 필요성이 높지 않아, 오히려 3사 엔진 중 가장 무거운 중량과 크기가 단점으로 부각되었다. 이와 같이 제품화 초기부터 예상에 못 미치는 결과가 나타나자, $\mathrm{GE}$ 는 2가지 전략을 마련하였다. 그것은 (1) 장기 비전 수립과 이에 부합하는 지속적인 투자 및 기술혁신과 (2) 고객 가치(Customer Value)를 실현 방법에 대한 혁신이다.

4) 국제민간항공기구(ICAO)에서는 쌍발 제트엔진 항공기에 대하여 ETOPS(Extended-range Twin-engine Operational Performance Standards) 규정 준수를 요구(즉, 2 개의 엔진이 달린 항공기가 운항 도중 하나의 엔진 고장 시, 비상 착륙 공항까지 특정 시간 동안 운항할 수 있는 인증제도). 
특히, 두 번째 전략이 현재 $\mathrm{GE}$ 의 Predix가 $4 \mathrm{IR}$ 의 대표적 사례로 거론됨을 주지할 필요가 있다. GE는 일반적으로 수요자는 변화를 싫어하는데, 이는 변화가 최소화되어야 총소유비용 (Total Cost of Ownership)에 대한 예측이 가능하기 때문이라는 결론을 도출하였다. 또 GE90 개발 초기에 생각한 기회가 수요자에게 오히려 리스크로 해석될 수 있음을 인지하게 되었다. 이에 GE는 'Power-by-the-Hour'5)라는 개념을 도입하여, 기존의 항공기 엔진 구매 시 활용 되던 자본재 리스 개념에 수요자가 수리 및 운전 비용을 모두 통합하여 감안할 수 있는 방안을 고민하였다. 이에 $\mathrm{GE}$ 는 현지 공항에 별도 유지·보수 시설을 약속하는 마케팅과 동시에 최적성능 가동시간 증가와 유지·보수 시간 최소화를 위한 방안을 모색하게 되었다. 예를 들어, 같은 엔진 기종이라도 다른 노선을 운항하는 경우에는 성능이 다르게 나타나고 있었는데, 이는 해당 지역의 공기 질, 기상, 조종사의 운항 습관 등 다양한 운항 조건과 부품의 마모 패턴 등 수많은 엔진 성능 요인과의 상관관계 때문이다. 따라서 이들 조건에 대한 장기간의 데이터 축적과 분석을 수행하여 대응 관리 방안도 마련하게 된 것이다. 즉, 1990년대 중반부터 엔진 운전 조건의 지속적인 모니터링과 즉각적인 분석을 통한 예지 정비 등의 개념을 직접 추진하기 시작하였으며, 이들 플랫폼이 Predix라는 전사적 플랫폼으로 통합 및 구축하여 운영하는 단계까지 이르게 된 것이다.

다시 말해, 민간 주도로 $4 \mathrm{IR}$ 이 추진되는 미국의 경우에도 현장의 대응은 우리가 생각하는 것보다 훨씬 그 오래되었다는 것을 알 수 있다. 다시 말해, 우리가 주목하는 성과는 소위 번득이는 아이디어 및 단기간의 기술 개발보다는 미래 위험에 대한 절박한 인식과, 이에 대응하는 장기적인 전략 마련은 물론 20년이 넘는 장기간의 지속적이고 일관성 있는 노력의 결과로 보아야 할 것이다. 아울러, 이와 같은 오랜 기간 동안 꾸준하고 지속적인 노력 이외에도 $\mathrm{GE}$ 가 주목한 점은, $\mathrm{IT}$ 이외에도 이를 적용할 생산기술에 대한 혁신 역시 중요하게 여겼다는 것이다. GE는 이를 'BIG IRON + BIG DATA = BIG OUTCOMES'로 표현하고 있음을 주목할 필요가 있다.

5) 'Power-by-the-Hour'는 1960년대 초반 영국의 항공기 엔진 제조사인 Bristol Siddeley에서 최초로 고안되었고, 1966년대에 동사를 인수한 Rolls Royce사가 이를 계승 및 발전시켰으며, 동 개념에 대한 상표권을 보유하고 있음. 


\section{III. 국가별 추진 현황}

\section{1. 주요 선진국}

4차 산업혁명에 대한 대응 전략에 있어서 각 국가는 차이를 보이고 있다. 독일, 미국 등 4IR 선도국은 물론 다른 강소국도 자국의 실정을 감안하고, 보다 상위 개념인 국가(과학기술) 혁신 전략과의 일관성 및 연계성을 고려하기 때문이다.

독일의 Industrie 4.0 전략은 독일의 과학기술혁신 정책인 New High-Tech Strategy(NHS)의 세부 프로그램6)으로 운용 중이며, 유럽연합(European Union, 이하 EU) 'Horizon 2020'의 하부 프로그램인 'Factories of the Future'와도 밀접하게 관련되어 추진되고 있다. 본 전략은 제조업과 IT 시스템을 결합한 스마트 공장 추진이 핵심이며, 그 배경에는 제조업 비중의 하락과 생산인구 감소에 대한 대응 및 고임금 사회 추구와 에너지를 포함한 자원 효율성 추구가 있다. 따라서 동 전략에서는 중소기업의 경쟁력 유지와 고임금 노동자 시대에 부합하는 미래 노동의 형태 설계를 중요시하고, 중소기업을 위한 Mittelstand 4.0 및 일자리 전략인 Arbeiten 4.0과 연계되어 추진되고 있다.

반면, 미국은 GE, IBM(International Business Machines Corporation) 등 미국 기업과 보쉬(Bosch) 및 화웨이 등 타국 기업을 포함하여 결성된 산업인터넷 컨소시엄(Industry Internet Consotium, 이하 $\mathrm{IC}$ )을 중심으로 관련 사업을 추진하고 있다. 이는 사업 추진의 효율성을 증대 시키는 IT 분야에서 사업 모델을 창출하는 데 목적이 있다. 따라서 이들 추진 전략은 수익 극대화 및 IT 분야에서 미국의 거점·패권화 전략의 관점이 강하며, 중소기업 및 일자리에 대한 관심은 상대적으로 낮은 편이다.

한편, 미국과 독일은 자국의 산업 현황을 기반으로 $4 \mathrm{IR}$ 주도권을 장악하기 위하여 $\mathrm{IT}$ 와 OT 시장을 양분하는 전략을 구사하는 것으로 인지되고 있으며, 2016년도부터 관련 정책 및 사업 추진 기관인 독일의 Plattform Industrie 4.0과 미국의 IIC 간의 본격적인 협력 관계 역시 이를 반증하고 있다.

최근에는 이들 국가 이외에도 영국 및 프랑스뿐 아니라 싱가포르, 스웨덴, 오스트리아, 이탈리아, 스페인, 벨기에, 호주 및 아시아의 대만, 말레이시아 및 태국 등이 자국의 기술 및 산업 현황과

6) Industrie 4.0은 NHS의 5대 중점 요소 중 하나인 'Priority challenges with regard to value creation and quality of life' 과제에 포함된 5 대 과제 중 하나인 'The digital economy and society'의 8개 프로그램 중 하나에 해당 
연계하여 차별화된 비전과 전략을 추진 중이다. 또한 베트남 및 인도네시아 등도 2017년도부터 범국가적인 관심이 집중되고 있다. 예를 들어, 싱가포르의 경우에는 고학력 인재를 활용할 수 있는 데이터 중심의 의료바이오 연구 개발(Research and Development, 이하 R\&D), 기존의 항공기 $\mathrm{MRO}$ 기지의 강점과 글로벌 가치사슬을 감안하여 $\mathrm{MRO}$ 기지의 스마트 생산 공장 전환, 관련 로봇 응용 연구 허브화, 바이오 및 항공 연계 적층가공 기술개발 등에 매진하고 있다.

〈표 2〉 주요 국가별 $4 \mathrm{IR}$ 관련 정책 동향

\begin{tabular}{|c|c|c|c|}
\hline 구분 & 국가 & 정책 유형 및 방향 & 4차 산업혁명 대응 동향 및 특징 \\
\hline \multirow{4}{*}{$\begin{array}{l}\text { 전통 } \\
\text { 제조 } \\
\text { 강국 }\end{array}$} & 독일 & $\begin{array}{l}\text { - 프로젝트형·패권형 } \\
\text { - 추진 기간 : 장기 } \\
\text { - 인간과 기계의 협업 } \\
\text { - 독일 제조업의 경쟁력 유지 } \\
\text { - 스마트공장 : 독일 생산기 } \\
\text { 술로 세계 석권, 세계의 공 } \\
\text { 장을 만드는 공장의 지위 } \\
\quad \text { 확보 }\end{array}$ & $\begin{array}{l}\text { - 추진 주체 : 대·중·소기업, 협회 및 산학연 연계와 강력한 } \\
\text { 정부 지원 } \\
\text { - 주요 컨소시엄 : Plattform Industrie } 4.0 \\
\text { - 인더스트리 4.0을 통해 제조 혁신의 전반적 프레임 제시 } \\
\text { - 서비스를 포함한 성공적인 혁신을 도모하기 위해 Smart } \\
\text { Service World 2025('15) 추진 } \\
\text { - 표준 : De Jure Standard(산업표준화 추진 후 국제표준화) } \\
\text { - 사례 : Audi AGV 등 }\end{array}$ \\
\hline & 미국 & $\begin{array}{l}\text { - 거점형·패권형 } \\
\text { - 추진 기간 : 중장기 } \\
\text { - 인간관점 별무 } \\
\text { - 기존 시설 - 장비의 전략적 } \\
\text { 활용 } \\
\text { - IT 기술에서 사업 모델을 } \\
\text { 창출하여 수익 원천 확보 } \\
\text { - 설계·제조 및 신소재 관련 } \\
\quad \text { 신 프로세스 개발 }\end{array}$ & $\begin{array}{l}\text { - 추진 주체 : 대기업 위주, IT 기술 위주, 산학연 연계 미흡 } \\
\text { - 주요 컨소시엄 : IIC(Industrial Internet Consortium) } \\
\text { - 제조업 자체보다는 제조 혁신을 도모하기 위한 산업인터넷, } \\
\text { 3D 프린팅 등 새로운 영역 집중 } \\
\text { - 첨단 제조 파트너십(AMP), 선진제조연구시설(IM) 설치 등을 } \\
\text { 통한 첨단제조 육성 지원 및 Smart America Challenge } \\
\text { ('13), New Innovation America('15) 프로그램을 통해 } \\
\text { 사업기회 적극 발굴 } \\
\text { - 표준 : De Facto Standard(시장 경쟁하에서 국제표준화) } \\
\text { - 사례 : GE Predix 등 }\end{array}$ \\
\hline & 일본 & $\begin{array}{l}\text { - 민생해결형·주력산업형 } \\
\text { - 추진 기간 : 중·단기 } \\
\text { - 인간중심 자동화, 히토즈쿠리 } \\
\text { - 기존 공정 생산성 제고 } \\
\text { - 설비·공장·공정의 미시적 } \\
\quad \text { 관점에서 방안 모색 } \\
\text { - 기존 강점 제품 기반으로 } \\
\text { 로봇 등 신산업 분야 집중 } \\
\text { - 산업인터넷 컨소시엄 출범 } \\
\quad \text { 및 빅데이터·인공지능 분야 } \\
\quad \text { 투자 확대 }\end{array}$ & $\begin{array}{l}\text { - 추진 주체 : 로봇·부품 관련 대기업, 중소 전문 기업, } \\
\text { 산학연 연계 초기 } \\
\text { - 주요 컨소시엄 : IVI(Industry Value Chain Initiative) } \\
\text { - 제조업 보완 관점에서 4차 산업혁명을 추진하고 있어 } \\
\text { 독일, 미국보다는 보수적인 접근을 취하고 있음. } \\
\text { - 로봇, 기계, 제어계측 등 일본이 강점을 나타내는 분야에 } \\
\text { 초점 } \\
\text { - 최근 빅데이터, loT 등 IT 분야의 전반적인 경쟁력 제고 } \\
\text { 방안을 포함한 신산업구조비전('15)과 4차 산업혁명 } \\
\text { 선도전략(' } 16) \text { 을 발표 } \\
\text { - 표준 : Loose Standard(기밀과 공개를 동시 추구) } \\
\text { - 사례 : Edge Computing 등 }\end{array}$ \\
\hline & 중국 & $\begin{array}{l}\text { - 복합추구형·패권형 } \\
\text { - 제조 대국에서 제조 강국 } \\
\text { 으로의 전환 } \\
\text { - 제조업 및 인터넷 강국을 } \\
\text { 목표로 정부 중심의 전략 } \\
\text { 수립 }\end{array}$ & $\begin{array}{r}\text { - 거대 내수시장 기반으로, 정부 주도 신산업 혁신 전략 추진 } \\
\text { - 중국제조2025 : 세계 최고 수준의 제조 강국 비전을 제시 } \\
\text { 하고, 이를 위한 신산업 중심의 제조혁신 } \\
\text { 전략 마련 } \\
\text { - 인터넷플러스 : 기존 제조업을 한 단계 발전시키기 위한 } \\
\text { 수단으로 ICT 기술 활용 }\end{array}$ \\
\hline
\end{tabular}




\begin{tabular}{|c|c|c|c|}
\hline 구분 & 국가 & 정책 유형 및 방향 & 4차 산업혁명 대응 동향 및 특징 \\
\hline \multirow[b]{2}{*}{$\begin{array}{l}\text { 강 } \\
\text { 소 } \\
\text { 국 }\end{array}$} & $\begin{array}{l}\text { 싱가 } \\
\text { 포르 }\end{array}$ & $\begin{array}{l}\text { - 민생해결형·신산업형 } \\
\text { - 우수한 인재 중심의 고부가 } \\
\text { 가치 제조업 육성 } \\
\text { - 전략산업과 연계 }\end{array}$ & $\begin{array}{l}\text { - 항공, 전자부품, 화학, 바이오의료, 해양플랜트, 물산업 등 } \\
\text { 자국의 전략산업을 중심으로 선택과 집중적 정책 추진 } \\
\text { - 싱가포르 i4.0은 특정 기술 분야에서 싱가포르에 진출한 } \\
\text { 다국적 기업과 연계한 현장 중심적 산학연 프로그램 마련 }\end{array}$ \\
\hline & 호주 & $\begin{array}{l}\text { - 문제해결형 } \\
\text { - 제조업 부활 : 기존에 우수한 } \\
\text { 경쟁력을 보유하고 있는 기술 } \\
\quad \text { 및 산업과의 연계 }\end{array}$ & $\begin{array}{l}\text { - 4차 산업혁명을 계기로 식음료, 의료, 석유·가스, 광공업, } \\
\text { 적층제조 등 자국이 강점을 보유한 분야의 혁신 도모 } \\
\text { - 기업, 협회 등 민간 차원에서 4차 산업혁명 대응 필요성이 } \\
\text { 제기되었고, 호주 정부는 국무총리 직속의 Industry } 4.0 \\
\text { TF를 } 2016 \text { 년 } 4 \text { 월에 결성하여 국가혁신계획과 연계한 } \\
\text { 대응방안 추진 }\end{array}$ \\
\hline
\end{tabular}

출처: 김상훈 (2017c)에서 재인용

\section{제 I 장}

\section{2. 아세안(ASEAN) 국가}

4IR이 일자리, 국가 간 교역·협력 및 산업구조 재편 등 사회 전반에 상당한 파급효과를 미칠 것으로 예상된다. 이에 따라 그동안 관련 이슈에 상대적으로 관심이 소홀했던 개발도상국은 물론, 최근에는 저개발국에서조차 $4 \mathrm{IR}$ 에 대한 상당한 관심을 표현하고 있는 상황이다.

특히, 중국과 함께 전 세계 제조 기지의 한 축을 담당하고 있으며, 하나의 권역을 지향하는 아세안 국가의 $4 \mathrm{IR}$ 에 대한 관심 증가는 물론 관련 정책을 마련하기 위한 노력도 활발하게 진행되고 있다. 또한 보쉬(Bosch) 등 이들 국가에 제조 현장을 확보하고 있는 다국적기업은 물론, 아세안 국가의 구매력평가지수가 상대적으로 높게 상승하고 있다는 점에서 다른 기업들 역시 아세안 국가에 대해 높은 관심을 보이고 있다.

아세안 국가 중 싱가포르를 중심으로 말레이시아와 태국은 이미 수년 전부터 관련 정책을 추진 중에 있으며, 베트남과 인도네시아는 2017년부터 본격적인 대응 움직임을 보이고 있다. 특히, 이와 같은 국가별 대응 순서와 수준은 각 국가의 디지털화 수준과 무관하지 않은 것으로 보인다. 
〈그림 4〉 아세안(ASEAN) 국가의 디지털 경제 대응 수준

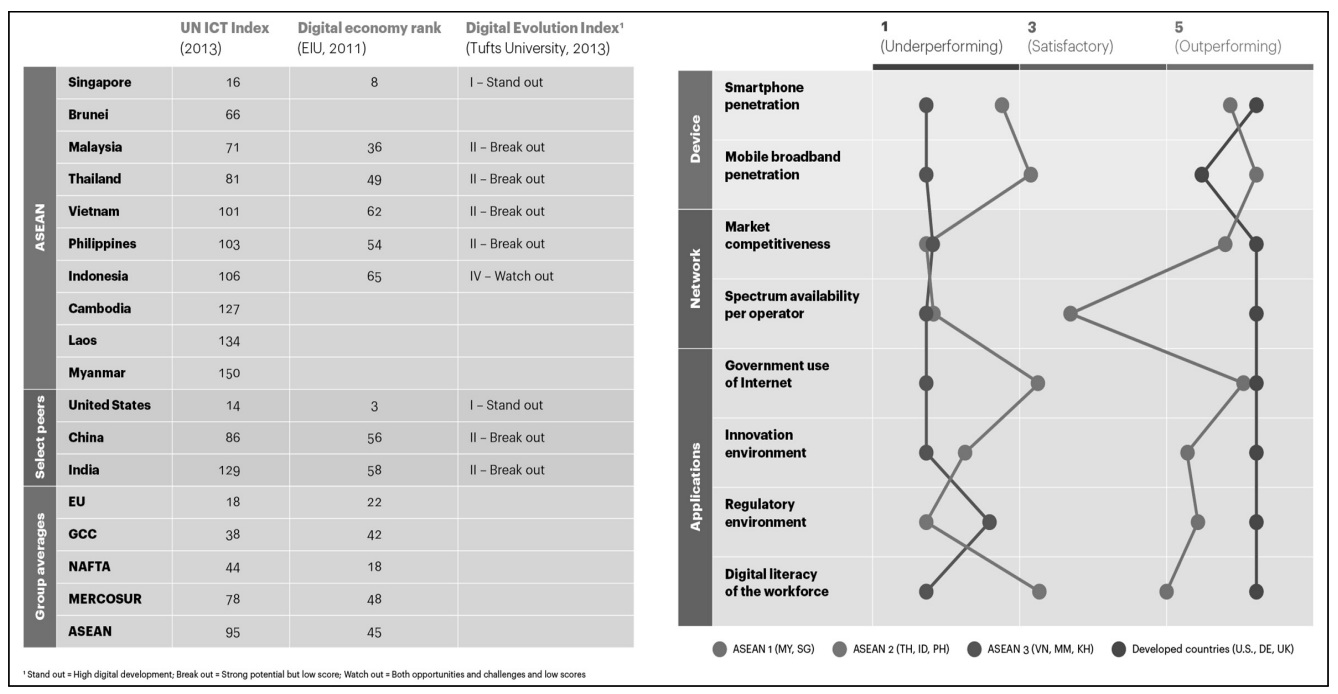

출처: Chua(2015)에서 재인용

아세안 국가 중 이미 상당한 정책을 추진 중인 국가 중 선진국 수준인 싱가포르와 말레이시아 및 태국의 관련 정책을 간략하게 살펴보면 다음과 같다.

우선, 싱가포르는 자국의 경제 규모 및 국가의 특징을 감안하여 싱가포르에 진출해 있는 다양한 다국적기업과 연계하고자 하는 측면이 강하다. 또한 전략산업으로 삼고 있는 항공, 전자, 바이오, 항만 및 물 산업을 중심으로 특정 기술 분야에 대한 산학연 프로그램 등을 추진하여 해당 기술의 현장 접목을 가속화할 수 있는 구체적인 분야의 선정 및 집중 전략이 그 핵심이다. 그러나 다른 국가들과는 달리 거시적 접근보다는 기업에서 빠른 수용이 가능한 부분을 도출하여 추진하는 전략을 구사하고 있다. 상기 내용과 더불어 싱가포르는 스마트시티(smart city) 구현에 대규모 투자를 추진하고 있으며, 전 세계적으로도 가장 앞선 단계로 평가받고 있다.

〈표 3〉 Singapore i4.0 추진 체계

\begin{tabular}{|c|c|c|c|}
\hline \multicolumn{4}{|c|}{ 목표 : 산업과 기업의 빠른 수용을 촉진 } \\
\hline 전략 방향 & 선행 작업 & 세부 프로그램 & 참여 기관(성공 사례) \\
\hline $\begin{array}{l}\text { 기술 역량의 } \\
\text { 발전을 도모 }\end{array}$ & $\begin{array}{c}\text { 산업계와의 협력을 } \\
\text { 통한 산업 수준에서의 } \\
\text { 기술로드맵 작성과 } \\
\text { 전략 기획 }\end{array}$ & $\begin{array}{l}\text { - 스마트 로보틱 } \\
\text { - 적층가공 } \\
\text { - 제조 분야 빅데이터 분석 }\end{array}$ & 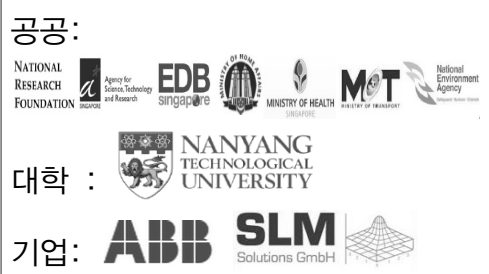 \\
\hline
\end{tabular}




\begin{tabular}{|c|c|c|c|}
\hline \multicolumn{4}{|c|}{ 목표 : 산업과 기업의 빠른 수용을 촉진 } \\
\hline 전략 방향 & 선행 작업 & 세부 프로그램 & 참여 기관(성공 사례) \\
\hline \multirow{2}{*}{$\begin{array}{l}\text { 산업과 } \\
\text { 기업의 변혁 }\end{array}$} & $\begin{array}{c}\text { (산업) 20개 산업 } \\
\text { 분야별 맞춤형 로드맵 } \\
\text { 구축 }\end{array}$ & $\begin{array}{l}\text { - 생산성 제고 } \\
\text { - 인력 양성 } \\
\text { - 기술 개발 } \\
\text { - 국제화 }\end{array}$ & \\
\hline & $\begin{array}{l}\text { (기업) 권역별 } \\
\text { 테스트베드 구축 }\end{array}$ & $\begin{array}{l}\text { - Manufacturing Control } \\
\text { Tower (MCTTM) }\end{array}$ & 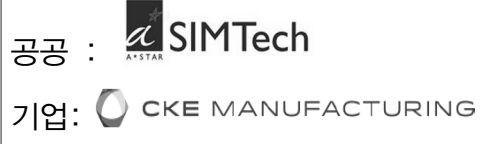 \\
\hline $\begin{array}{l}14.0 \text { 역량을 } \\
\text { 보유한 인력 } \\
\text { 확충 }\end{array}$ & - & $\begin{array}{l}\text { - 수요 재능 발굴 } \\
\text { - SKILLSFUTURE } \\
\text { (Employee } 4.0 \text { : 위험 } \\
\text { 및 필요 직업을 좋은 } \\
\text { 직업으로 변환) } \\
\text { - 산업수요 대응 인력 양성 } \\
\text { 프로그램 }\end{array}$ & 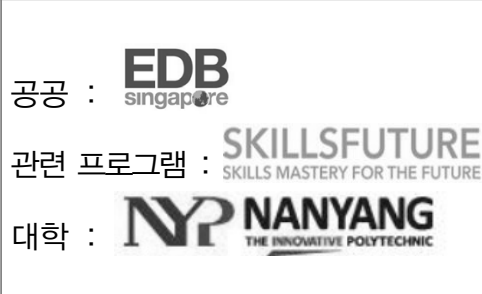 \\
\hline
\end{tabular}

\section{제 $\mathrm{I}$ 장}

개

발

협

력

이

슈

제II장

제피장

출처: 전문가 면담을 통해 저자가 재구성

한편, 상대적으로 발전된 자국 제조업을 보유하고 있는 말레이시아는 $11^{\text {th }}$ Malaysia Plan (2016-2020)의 제7장(Strengthening Infrastructure to Support Economic Expansion) 에서 제조업의 발전을 위한 스마트제조(smart mnufacturing)를 명시하는 한편, 이를 지원하기 위한 주요 분야로 적층 가공, 로보틱스와 관련된 비즈니스 모델의 발전을 제시하고 있다. 또한 스마트 제조를 가능케 하는 기반(backbone)으로, Big Data Analysis(BDA)와 IoT를 명시하고 있다. 이를 위해 자동화 또는 로봇 도입 시 비용 지원 또는 조세감면제도의 추진은 물론 M2M 연결, 공장 지능화, 정보 집적 관련하여 약 180 여 개의 시범 사업을 추진 중이며, 최근에는 관련 인재 육성 프로그램을 운영 중이다(말레이시아 투자청에서는 이와 관련하여 2016년 현재 1.3조 원 (RM4.9billion)에 해당하는 금액이 이미 투자된 것으로 보고하고 있다.). 
〈그림 5〉 태국의 Thailand 4.0

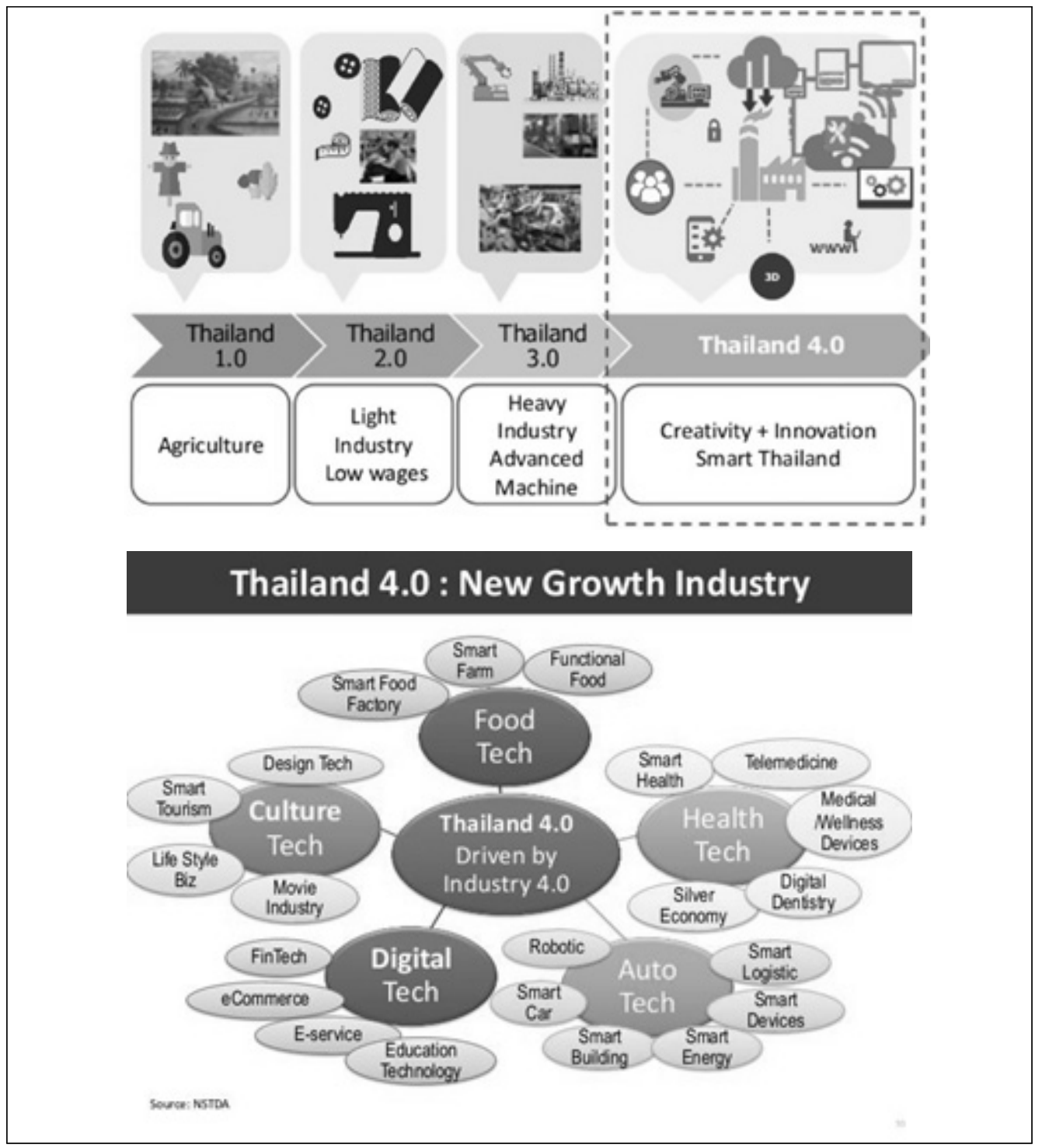

출처: Kaewsang (2016)

태국의 경우에는 Thailand 4.0을 태국의 $4 \mathrm{IR}$ 대응 캐치프레이즈로 삼고, 관련 정책을 역동적 으로 추진 중이다. 거시적인 측면에서 볼 때 Thailand 4.0 의 비전 역시 창의력, 혁신과 지식경제 달성이라는 측면에서 다른 나라의 모델과 크게 다르지 않다. 하지만, 산업적으로는 크게 농업과 제조업 및 문화산업의 세 산업을 중점 육성 대상으로 하고 있다. 세부적으로는 농업(스마트농장, 관련 식품 및 약품), 제조업(자동차 부품 관련 산업), 문화(관광, 의료)에 집중하는 한편, 이와 연계되는 금융 및 교육을 병행하는 구조로 되어 있다. 


\section{IV. 시사점 및 맺음말}

앞에서 4차 산업혁명(4IR)의 주요 개념과 오해, 발전 과정 및 국가별 관련 정책 추진 체계 등을

간략하게 살펴보았다. 이들 통한 주요 시사점은 다음과 같다. 첫째, $4 \mathrm{IR}$ 의 핵심이 디지털화에 있다는 것은 의심의 여지가 없다. 그러나 $4 \mathrm{IR}$ 은 IT 자체가 아닌 기존 생산기술, 즉 OT와의 공진화와 혁신이 무엇보다 중요하다는 것이다. 따라서 IT 이외에도 기존의 산업 또는 기술의 스마트화에 대응할 수 있도록 OT의 고도화가 병행되는 것이 필수적이다.

이와 같은 측면에서, 국가 간 협업 체계는 기존과 다른 형태를 보일 가능성이 충분하다. 예를 들면, 기존의 선진국에서 개발도상국으로의 기술이전 등 일방향적 협력 구조에서 양방향 협업 구조가 보다 효율적인 협력 체제로 부각되고 있는 것이다. 일부에서는 4IR이 Reshoring을 촉진하여 개도국에 상당한 위험 요인으로 예상하고 있으나, 보다 정확하게는 Reshoring의 결정인자가 다변화되어 오히려 개발도상국에 기회 요인이 될 수 있다고 보는 것이 적절하다.

예를 들어, 디지털화를 통한 초연결성이 강화되면 현재 문제로 부각되고 있는 품질관리, 물류 및 마케팅 효율성 등이 증가하여 Reshoring의 결정인자는 전통적인 임금 수준 이외에도 다양화될 것으로 기대된다. 다만, 이를 위해서는 개발도상국의 인적 자원 확보가 반드시 선행되어야 한다. 하지만, 여러 다국적기업의 관련 전문가와 탐문한 결과, 아세안 국가에서 인적 자원의 신기술에 대한 수용 의지는 선진국 노동자보다 높은 수준에 있으며, 상당 부분에서 한국 및 중국보다도 높게 나타나고 있다. 따라서 국가별로 관련 교육 프로그램만 적절하게 정비된다면 향후 전망을 비교적 낙관적으로 보고 있다는 점은 주목할 만하다.

〈표 4〉Reshoring의 결정 요인 예시

\begin{tabular}{|c|c|c|c|c|c|}
\hline & & \multicolumn{2}{|c|}{ 4IR 이전 } & \multicolumn{2}{|c|}{ 4IR 이후 } \\
\hline \multicolumn{2}{|c|}{ 요인 } & 과거 & 현재 & 대응 실패 & 대응 성공 \\
\hline 저임금 & \multirow{2}{*}{$\begin{array}{c}\text { 과거의 } \\
\text { 주된 결정 요인 }\end{array}$} & 0 & 0 & 0 & 0 \\
\hline 물류 효율 & & $\triangle$ & O & 0 & 0 \\
\hline 인적 자원 수준 & \multirow{2}{*}{$\begin{array}{c}\text { 향후의 } \\
\text { 주된 결정 요인 }\end{array}$} & $x$ & $x$ & $x$ & 0 \\
\hline 소비자 수요 대응 & & $x$ & $\triangle$ & 0 & 0 \\
\hline \multicolumn{2}{|c|}{ 생산 대응 } & Offshoring & Offshoring & Reshoring & $\begin{array}{l}\text { Reshoring } \\
\text { +Offshoring }\end{array}$ \\
\hline
\end{tabular}

출처: 전문가 면담을 통해 저자가 재구성

셋째, 각 국가는 자국의 국가.과학기술혁신체계, 산업구조 등을 감안하여 차별화된 전략을 구사할 필요가 있다는 것이다. 국가별 산업구조와 기술개발 잠재력이 다른 상황에서, $4 \mathrm{IR}$ 의 추진 체계 속에서 국가별 협업을 효율적으로 추진하기 위해서는 이 부분이 더욱 중요하다. 
아세안은 중국과 인도에 이어 세 번째로 많은 노동력을 보유하고 있으며, 2015년에 아세안경제 공동체(ASEAN Economic Community, $\mathrm{AEC}$ )의 공식 출범과 함께 10대 교역 블록으로 성장하였다. 이에 일부 전문가들조차 아세안의 발전이 진정한 아시아로의 회귀(pivot towards Asia)를 의미한다고 주장하고 있는 상황이다. 따라서 아세안 국가의 $4 \mathrm{IR}$ 추진은 아세안 내부적 으로나 주변 국가에 미치는 상당한 파급력이 있을 것으로 예상된다. 아직 싱가포르 등 일부 아세안 국가 이외에는 대부분 정책 도입 초기에 머물고 있어 구체적인 진행 상황을 파악하는 게 어렵지만, 한편으로는 효율적인 국가별 산업 협력과 체계를 마련하기 위해서는 이들 국가의 정책 도입기부터 다양한 대화 채널을 마련해야 한다.

4IR 선진국인 독일과 미국은 물론 중국과 일본 역시 그 중요성을 인식하고 양자 및 다자 간 국가 협력 체계를 구축하고 있지만, 국내 실정은 아직까지 관망세에서 크게 벗어나지 못하고 있는 것이 사실이다. 이를 위해 국내는 물론 해당국의 산업구조를 기반으로 한 협업 전략뿐 아니라 국가별 투하자본수익률(Return on Capital Employed, ROCE) 등의 실증 분석을 통한 국가별 추진 방향에 상호 갈등이 최소화될 수 있는 다각적 관점에서 전략을 마련해야 하며, 이를 실증하기 위한 시범 사업 등의 구축도 신중히 고려해 볼 필요가 있다.

\section{〈그림 5〉 국가별 ROCE의 변화 방향(제조업, 광업 및 유틸리티 분야)}

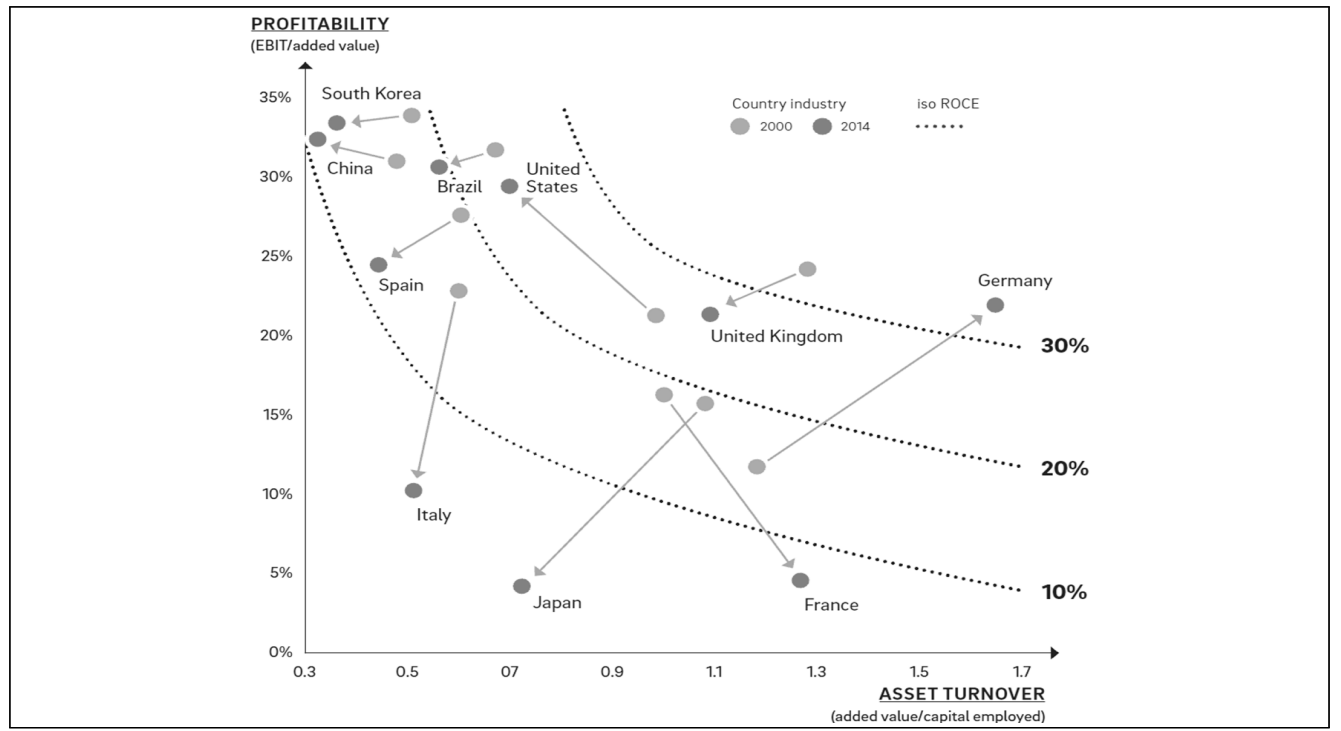

출처: Roland Berger (2016)

셋째, 성공적인 $4 \mathrm{IR}$ 추진은 장기간의 투자 및 기술개발과 일관된 정책이 지속되어야 한다는 것이다. 이에 대한 사례는 앞에서도 언급한 바 있다. 아울러, $4 \mathrm{IR}$ 추진을 위한 기술 간 융합을 다차원적이고 다각적인 관점에서 바라볼 필요가 있다. 중국의 경우에는 ‘중국 제조 2025 ’ 
‘인터넷 플러스'의 2차원적 관점에서 제조와 IT의 융합을 시도하고 있다. 또한 독일, 미국, 일본 등도 4차 산업혁명의 촉진자(Enabler)로서, IT의 수용자(adopter)로서 제조 기술의 다차원적인 융합을 시도하고 있다. 이와 같은 융합 패턴 역시 경우에 따라 국내 또는 국가 간 협업과 연계하는 것이 필요하다(독일과 미국의 Plattform Industrie 4.0과 IIC의 협력 등).

넷째, 앞서 언급한 국가별 추진 전략의 차별화와 연계한 전략적 글로벌 협력 추진이다. 앞서 언급한 바와 같이 $4 \mathrm{IR}$ 추진이 각국에 미치는 파급효과 및 우려 사항이 국가별로 차이가 있는 것은 자명하다. 따라서 각국의 실정에 맞는 전략 및 레퍼런스 모델 개발 등이 필요하며, 장기적인 관점에서는 글로벌 협력 생산체계 구축을 통한 효율적 생산구조의 확립이 필요하다.

예를 들어, 생산 측면에서 고임금 구조를 나타내는 선진국은 대량 생산과 맞춤형 제품 생산의 균형(scope)이 중요한 척도로 작용하지만, 저임금 국가에서는 대량 생산(scale)이 중요할 것이다. 따라서 전략 측면에서 선진국은 정교한 계획과 생산 시스템을 활용한 전략 최적화(planning orientation)가 중요한 반면, 개발도상국은 표준화된 안정적인 프로세스 기반의 비용 최적화 (value orientation)가 중요하게 작용한다. 이와 같이 서로 다른 국별 상황을 고려한 글로벌 협력 체계 구축 시 장기적으로 볼 때 생산 전략의 딜레마가 감소할 수 있을 것으로 기대된다. 즉, 효과적인 글로벌 협력을 위해서는 생산 및 전략 측면의 효율 사이에서 협력 국가의 실정에 적합한 균형점이 다를 수 있으며, 이를 감안한 협력 체계의 구축이 필요하다.

\section{〈그림 6〉 생산 방식의 통합과 글로벌 협력}

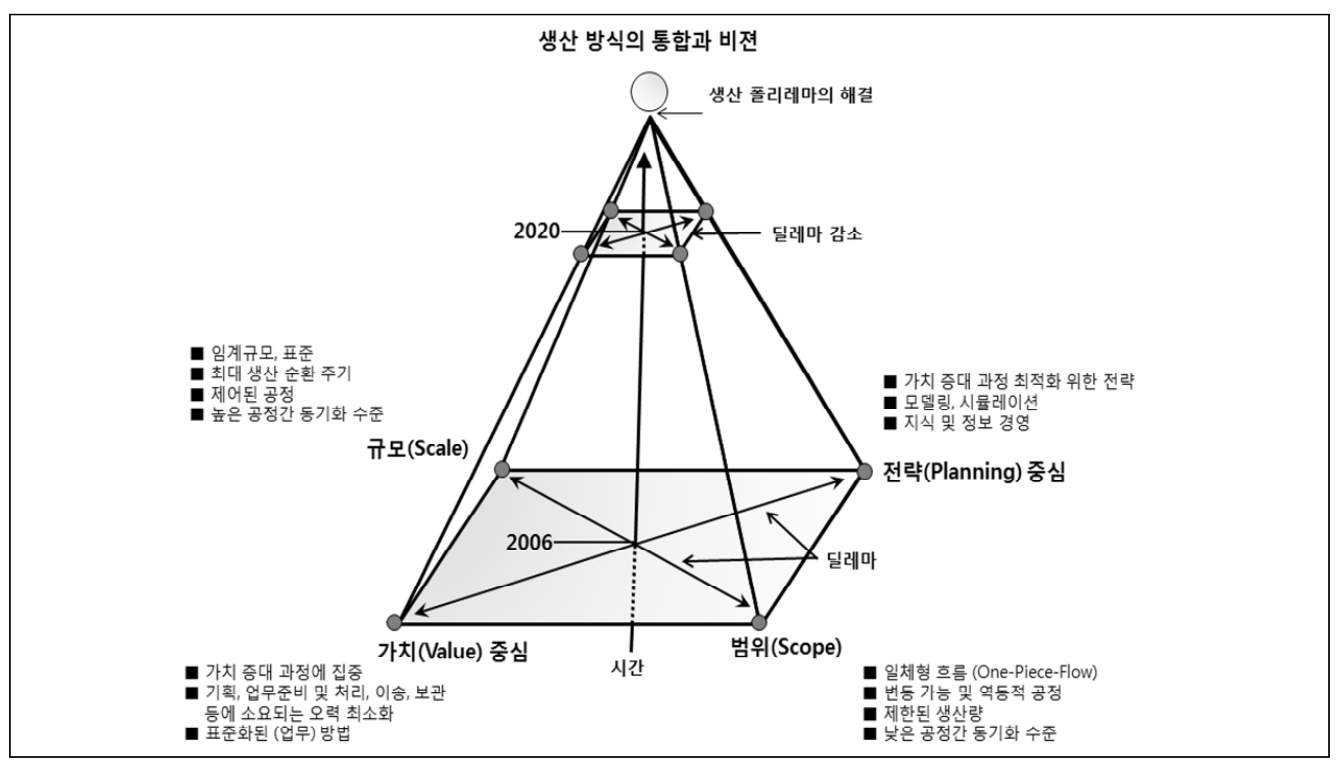

출처: Brecher (2012)를 참조하여 저자가 재구성 
마지막으로, $4 \mathrm{IR}$ 추진은 제조업뿐 아니라 우리의 미래에 많은 변혁을 가져다줄 것이 분명하다. 하지만, 이와 같은 변혁은 긍정적 효과 이외에도 다양한 부정적 효과도 가져다줄 수 있다. 예를 들면, 보안 등 기술적 측면은 물론 고용 형태, 인간 - 기계 간 소통을 포함한 다양한 사회적·문화적 측면에서 수많은 장애 요인을 포함한다. 따라서 성공적인 4 차 산업혁명에 대응하기 위해서는 이들 장애 요인 및 부작용에 대한 선제적 검토가 병행되어야 할 것이다. 


\section{〈참고 문헌〉}

김상훈. 2017a.『4차 산업혁명과 제조업 부문의 경쟁력 강화방안』. 국회보. 2017b. “4차 산업혁명과 산업별 혁신 전략”. 전력연구원 발표자료. 2017c. “4차 산업혁명: 기본 개념과 사례”.『월간산업경제』. 세종: 산업연구원. 김상훈·심우중. 2015. “미래 제조혁신을 위한 스마트공장의 이슈와 과제”. ${ }^{\mathrm{e}} \mathrm{e} \mathrm{KIET}$ 산업 경제정보』vol.620. 세종: 산업연구원.

. 2016. “제조혁신과 소재산업”.『이슈페이퍼』2016-401. 세종: 산업연구원. 2017.『4차 산업혁명과 뿌리산업 발전 방향』 수탁과제보고서. 세종: 산업

연구원.

엄은희. 2017. “4차 산업혁명과 아세안” 『동남아 이슈페이퍼』Vol.20. 서울: 서울대학교 아시아연구소.

장윤종·김상훈·이상현. 2018. “독일 인더스트리 4.0 전략의 확산발전 동향과 정책적 시사점”. 『정책연구』. 세종: 산업연구원.

Anderson, C. 2014. Makers: The New Industrial Revolution. New York: Crown Business.

Brecher, C. 2012. Integrative production technology for high-wage countries. Berlin: Springer.

Chua, S. G., and Dobberstein, N. 2015. “The ASEAN Digital Revolution”. Chicago: ATKearney.

Kaewsang, C. 2016. “Thailand 4.0”, from Smart Manufacturing Asia.

Kaufman, M. 2012. “The internet revolution is the new industrial revolution" posted in Forbes website on 5th October, 2012, available at https:// www.forbes.com/sites/michakaufman/2012/10/05/the-internet-revolution -is-the-new-industrial-revolution/\#1d03ef7a47d5 (접속일 2018.05.21.).

Kopetz, H. 2014. "From embedded systems to systems of systems" presented at the IEEE 17th International Symposium on Object/Component/ServiceOriented Real-Time Distributed Computing (ISORC)) on June 10th 12nd June, 2014 at Reno, Nevada.

Roland Berger, 2016. “The Industrie 4.0 transition quantified”. Munich: Roland Berger Gmbh. 
Saad, NS., 2016. "Moving Beyond the Learning Curve: The Regional Regulatory Scenario on Industry 4.0 Integration”, from Smart Manufacturing Asia. Ward, M. 2016. "Fourth Industrial Revolution” in Debate Pack of House of Commons, UK, held in the commons Camber on 8th September, 2016.

Westkamper, E.; Gottwald, B.; Fisser, F. 2005. "Migration of the digital and virtual factory to reality", CIRP Journal of Manufacturing Systems vol.34(5): 391-6. 